\title{
Primary Hydatid Cyst of the Musculoskeletal System Involving the Femur and Vastus Lateralis
}

\author{
Femur ve Vastus Lateralis Tutulumu Olan Primer Kas Iskelet Sistemi Kist Hidatiği
}

(D) Fatih Hakan Tufanoğlu

Kars Sarıkamış State Hospital, Clinic of Radiology, Kars, Turkey

\section{Dear Editor;}

Thirty-six-years-old female patient applied to physical therapy clinic due to local swelling on left anterior femoral area. The patient stated she had accompanying pain, and had no neuropathic pain complaints such as numbness and tingling. She had no known history of trauma, she was not diagnosed with a chronic and rheumatic disease. She did not spend time abroad and she had no close contact with dogs. In physical examination, a mobile, sensitive mass was observed in anterior femoral area. No accompanying ecchymosis, erythema or lymphadenopathy was determined. Muscle strength and sensory examinations was normal. Routine laboratory tests were normal. Direct X-ray of this area revealed a lytic lesion in left femur neck and proximal metaphysodiaphysis with narrow zone of transition. Pathologies such as fibrous dysplasia and aneurysmal bone cyst were considered for differential diagnosis. Patient was evaluated with scintigraphy which showed a photopenic appearance in phase 3 in the proximal of left femur. On magnetic resonance imaging, thin-walled cystic lesion with multicystic appearance were observed in left vastus lateralis muscle with hyperintense signal on T2w series, and hypointense signal on T1w series (Figure 1). Also, a lesion was observed in $\mathrm{T} 2 \mathrm{w}$ series with heterogeneous hyperintense signal in the femur neck at proximal diaphyseal level with medullary location, which caused slight expansion of the bone (Figure 2). The indirect hemagglutination test that was performed due to suspicious appearance was determined to be positive $(+1 / 640)$, and the diagnosis was determined as hydatid cyst with both muscle and bone involvement. Total joint prosthesis operation was planned for the patient. Lamellar membrane of hydatid cyst, mixed inflammatory cells, hystiocytes and necrosis were observed in histopatological examination. After the operation, albendazole $400 \mathrm{mg} /$ day pharmacological treatment was applied for weeks. No signs of local relapse were observed in the last examination of patient at post-operative follow-up year 1. Hydatid cyst is a zoonosis caused by the larval form of Echinococcus Granulosus, which

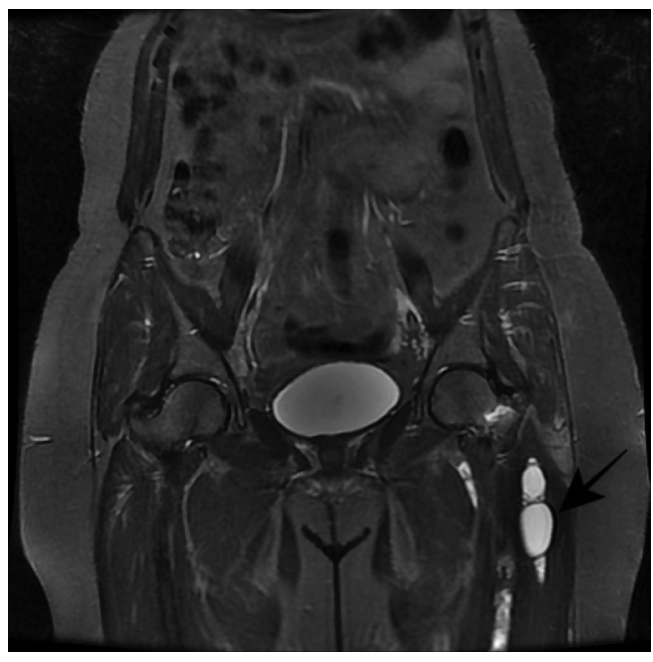

Figure 1. Cystic lesion with multicystic appearance were observed in left vastus lateralis muscle with hyperintense signal in $T 2 \mathrm{w}$ series

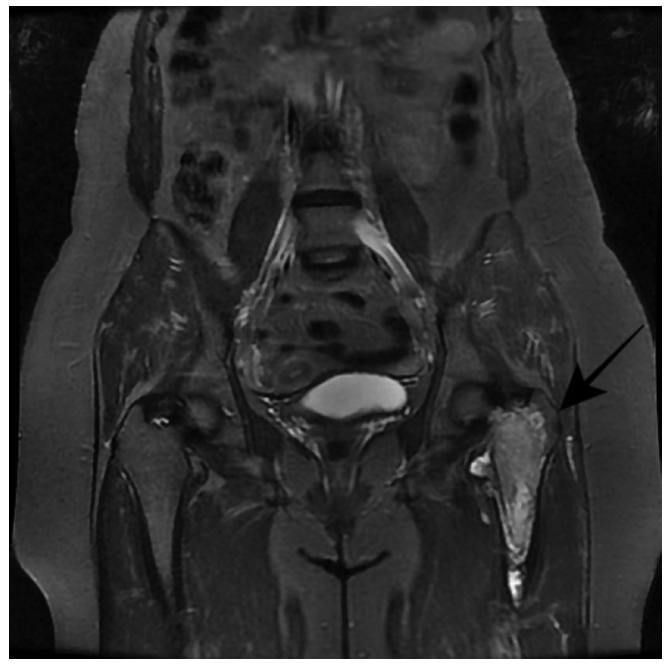

Figure 2. Heterogeneous-hyperintense signal lesion in the femur neck at proximal diaphyseal level with medullary location, which caused slight expansion of the bone

Address for Correspondence/Yazışma Adresi: Fatih Hakan Tufanoğlu MD, Kars Sarıkamış State Hospital, Clinic of Radiology, Kars, Turkey Phone: +90 5060600326 E-mail: fht13@hotmail.com ORCID ID: orcid.org/0000-0002-6720-1937 Received/Geliş Tarihi: 13.08.2019 Accepted/Kabul Tarihi: 09.10.2019

${ }^{\circ}$ Copyright 2020 by the Turkish Osteoporosis Society / Turkish Journal of Osteoporosis published by Galenos Publishing House. 
is transmitted to humans by the consumption of infected food and direct contact with infected animal. It may cause morbidity with effect of pressure, being located at areas that may result in functional loss such as bones, and with complications such as opening to bile ducts, anaphylaxis. Liver is its most common area of residence (1). It has been reported in literature that it is observed in musculoskeletal system at $1 \%-5.4 \%$ rate (2). The reason why it is observed rarely in muscles is suggested to be that lactic acid formed in skeletal muscle contractions prevents the Hydatid cyst from settling in. It was reported in literature that it most commonly settles in psoas muscle. Cases with involvement of pectoralis major, biceps brachii, latissimus dorsi, adductor, gluteus maximus, quadriceps, gastro-soleus muscles were also observed (3). The main symptom of hydatid muscle cysts is local swelling felt by touch. Similar to literature, our case has applied complaining from local swelling, however, it was rare and atypical because bone tissue was also affected. Although isolated femoral bone involvement has also been reported, bone involvement generally shows asymptomatic course. Secondary infection gives symptoms after fractures or pressure on neighboring neuromuscular structures (4). While the diagnosis may be determined with medical history, clinical findings, laboratory tests and radiological examinations, surgical excision and histopathological examination are required for definitive diagnosis. Hematoma, abscess and tumor should be considered for differential diagnosis. AAspirations for diagnostic purposes may result in anaphylaxis and local spreading due to rupture hence it is important to be recognized before intervention. Surgery, interventional radiological methods (PAIR) and medical therapy (albendazole) may be used for treatment (5). In conclusion, differential diagnosis of hydatid cyst should be kept in mind in patients with local soft tissue swelling, it should be considered that adjacent bone tissue may be affected along with soft tissue involvement, and treatment planning should be performed accordingly.

Keywords: Vastus lateralis, hydatid cyst, femur Anahtar kelimeler: Vastus lateralis, kist hidatik, femur

Peer-review: Externally and internally peer-reviewed.

Financial Disclosure: The author declared that this study received no financial support.

\section{References}

1. Craig PS, McManus DP, Lightowlers MW, Chabalgoity JA, Garcia HH, Gavidia CM, et al. Prevention and control of cystic echinococcosis. Lancet Infect Dis 2007;7:385-94.

2. Çolak MC, Kocatürk H, Çelik R, Gürsan N. Biceps brachii kası içinde primer kist hidatik. J Med Sci 2010;30:406-9.

3. Bagcier F, Onaç O, Melikoglu MA. Hydatid Cyst Presenting with Mass That Localized in the Cruris Region. Türkiye Parazitolojii Dergisi 2016;40:54.

4. Ritabh Kumar, Gulati MS, Nag HL. MR appearances in a case of femoral ecchinococcosis. Skeletal Radiol 2000;29:235-8.

5. Khuroo MS, Wani NA, Javid G, Khan BA, Yattoo GN, Shah AH, et al. Percutaneous drainage compared with surgery for hepatic hydatid cysts. N Engl J Med 1997;337:881-7. 